\title{
Geoenvironmental assessment of magnesite deposit Jelšava - Dúbrava massif
}

\author{
SOŇA CICMANOVÁ \\ Geological Survey of Slovak Republic, Markušovská cesta 1, 05201 Spišská Nová Ves, SLOVAKIA; \\ cicmanova@gsrcsnv.sk
}

(Received October 2002 Accepted December 2002)

\begin{abstract}
This article gives basic information on two main groups of geoenvironmental impacts originated from mining and processing activities realised on magnesite deposit of the Jelšava Dúbrava massif: mining impacts from magnesite exploitation and impacts from magnesite processing. They differ in character (nature), time behaviour and scale.
\end{abstract}

Key words: environmental impacts, magnesite, mining, mineral processing

IGCP 443

\section{Geological and tectonic conditions, morphology and mineralogy of deposit bodies}

The magnesite deposit in Dúbrava Massif occurs in the Gemeric tectonic unit about $20 \mathrm{~km}$ to the west of the town of Rožňava (Fig. 1). It has Upper Carboniferous host rocks, and borders the northern margin of the Gemeric unit near the Lubeník-Margecany line, along which the Gemeric tectonic unit was overfaulted over the Veporic one.

The geological structure of the deposit area was studied by several authors. A. Abonyi and M. Abonyi have especially long-term knowledge and experience on exploration. They are the authors of many final reports and reserves calculations, studies and publications on magnesite deposits of Slovakia (Abonyi et al., 1972).

The magnesite deposit is hosted by a rock complex represented on the base by basalt formations with tuff and graphite schist intercalations ( ̌̌apo, 1988). Basalts represent an underlying bed for carbonate rocks - mainly dolomites with magnesite intercalations. The hanging wall is represented by siliceous conglomerates and dark sand phyllites. The length of the carbonate body with magnesite portions is about 4,500 $\mathrm{m}$ (known on the surface), following the direction E-W. Its maximal effective thickness is around $600 \mathrm{~m}$. It monoclinally declines to the south, and its contact with the underlying and overlying rocks is sharp. The inclination of the contact surfaces varies from 30 to $60^{\circ}$ (Fig. 2).
Substantial part of the carbonate body is built up by light-grey fine-grained diagenetic dolomite with irregular layers of coarse-grained metasomatic dolomite. Magnesite occurs as irregular bodies, layers and aggregates in dolomite. The contact of the magnesite with dolomite is particularly gradual.

One of the most important phenomena, conditional to properties of the carbonate body - especially in relation to mining and determining hydrogeological conditions of the massif - are the tectonic conditions of the deposit, they range and intensity with karstification. Tectonic conditions of the deposit area are characterized by zonal structure of individual geological-tectonic units with $50-60^{\circ}$ to SSE of general inclination of bedding and schistosity. This general arrangement is a result of rock complexes overthrust along two regional tectonic lines: northward lying Lubeník-Margecany line and in the south HrádokŽelezník line. Also Carboniferous sequences were displaced during the overthrusting of the Gemeric tectonic unit over the Veporic one. It is documented by oldest oblong tectonic structures of E-W direction, present in deposit. Minor planar tectonic structures have transversal N-S or NE-SW direction. These tectonic faults are steep $\left(80-90^{\circ}\right)$ and divide the carbonate body and deposit into mutually shifted blocks with several metres in amplitude. There are three tectonically divided parts of deposit: Dúbrava, Miková and Jedl'ovec. 


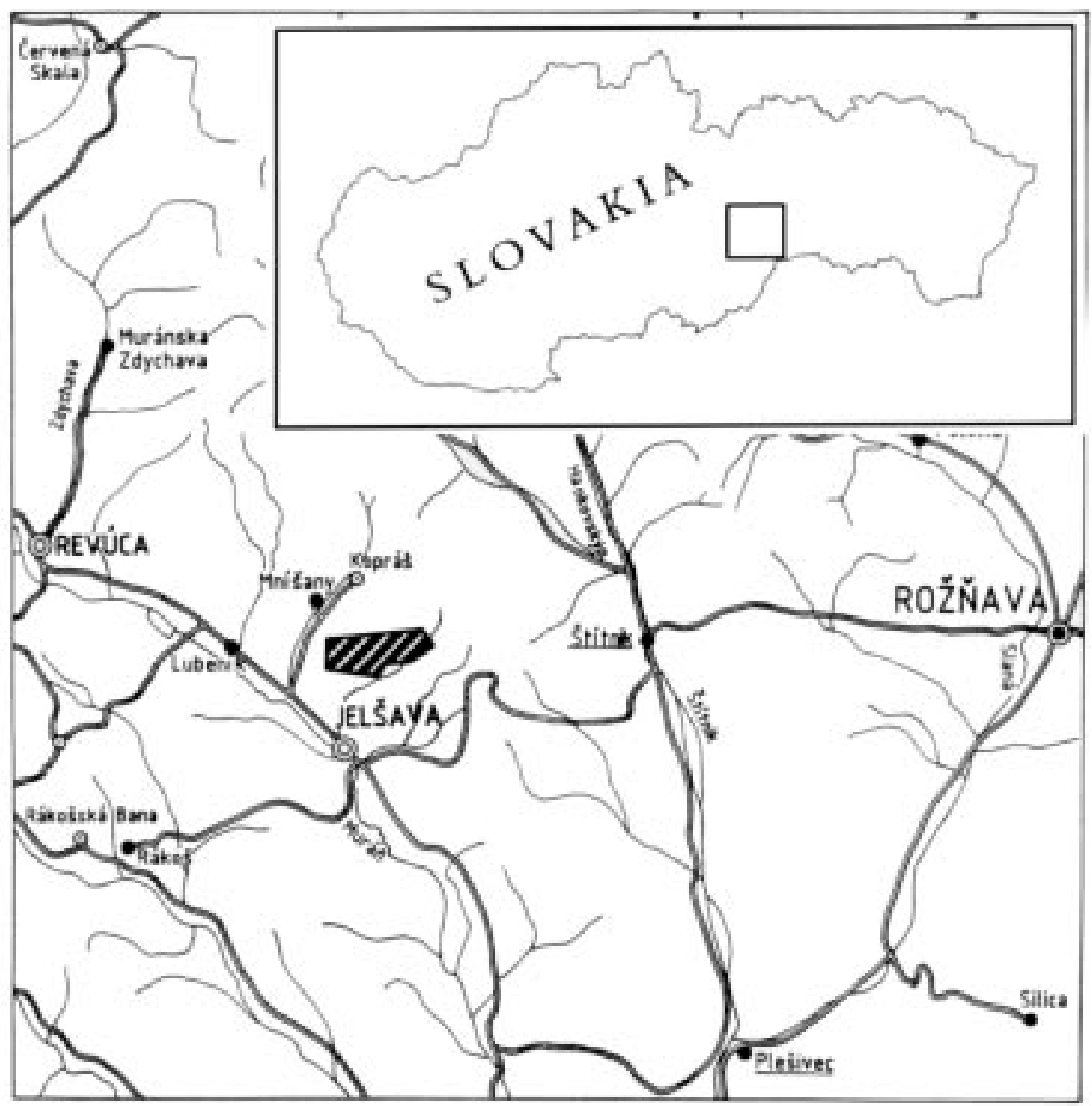

MAGNESITE DEPOSIT

Fig. 1. Jelšava magnesite deposit (situation map)

Western - Dúbrava - part of deposit has about 1000 $m$ in length , with average thickness of $70 \mathrm{~m}$. Central Miková - part is $800 \mathrm{~m}$ long, and its effective thickness is $400 \mathrm{~m}$. Eastern - Jedl'ovec - part is reduced in size and thickness to several metres.

\section{Geomorphologic, hydrogeologic and climatic conditions of the deposit area}

The deposit area belongs to the Paleozoic of Revúca upland in Slaná basin and is represented by a mountain massif with ground elevations named Dúbrava (683.6 metres above sea level), Miková (673.8 m) and Tatárka $(614.0 \mathrm{~m})$. The course of a meaningful overfault line is following the Jordan River valley of from the south and Mníšanský stream valley from the north-west. Both streams inflow into the Muránsky stream, which drains this area to the Slaná River, and represent the base erosion level of the territory (280-300 metres above sea level). North-south valleys in dolomite (magnesite) massif are bound to younger slip fault tectonics. The carbonate massif is poor in surface karst occurrences owing this to a good chemical resistance to water corrosion. Marks of fluviokarst relief occur there. Chemical corrosion is implied in a small scale and fluviokarst process of talus flushing prevails here. Secondary impact and the spread of long-term drainage of carbonate massif is represented by local origin of slots, 


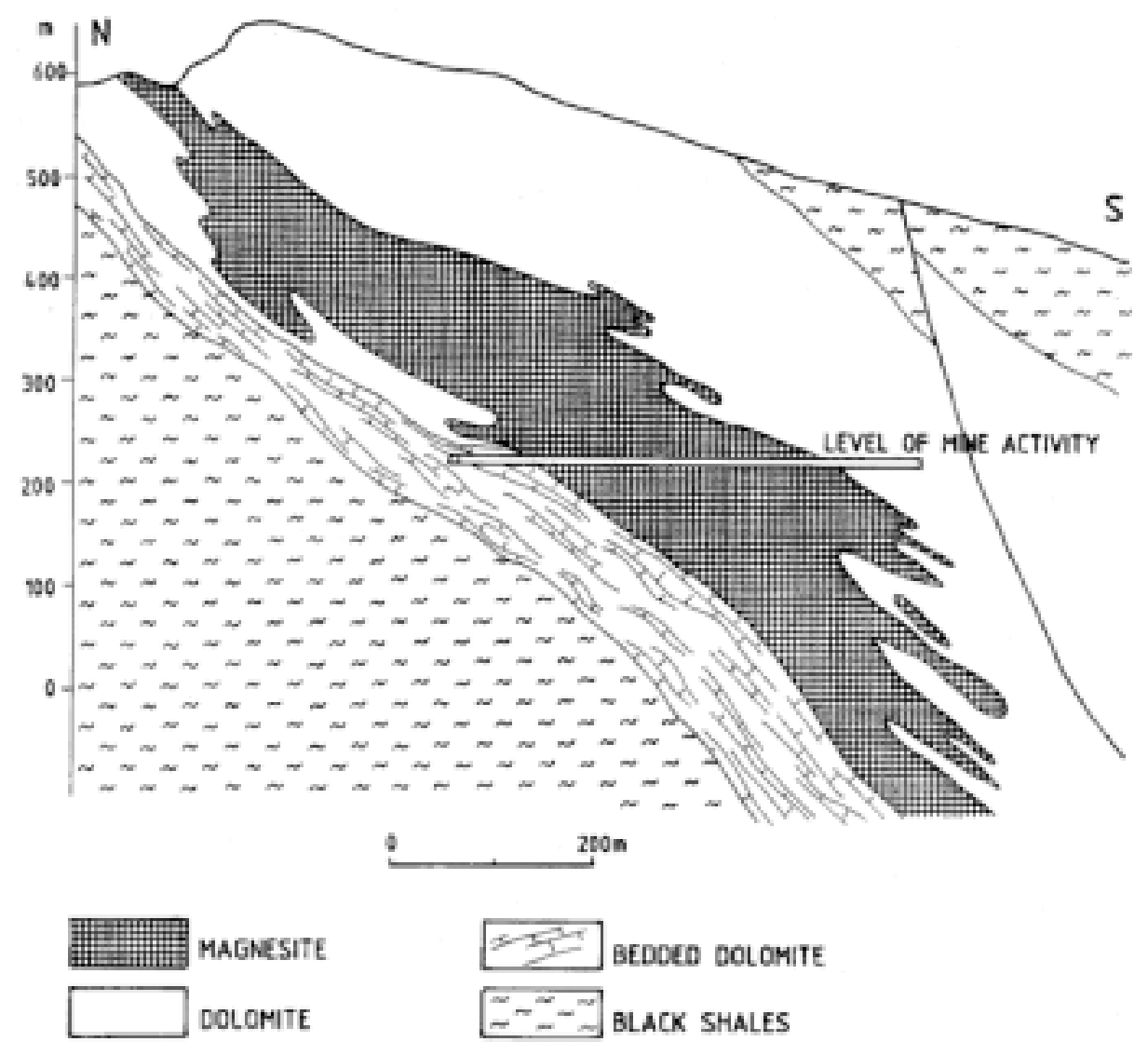

Fig. 2. Schematic cross-section of Jelšava magnesite deposit

especially in the tectonically weakened valley of the Jordan River.

The territory climate is of the warm-humid, mountain climate type, with low temperature inversions. It belongs to upland warm and humid area with temperate winters (Mazúr \& Lukniš 1980). Rain-snow type water runoff is applied here. High stream water level is in March and April, being lowest in September. Maximum of subsidiary stream water level is in the end of autumn and beginning of winter. Internal parts of Slovakia belong to the area with maximal intensity of rain lasting 15 minutes (thunder flood).

\section{Hydrogeological conditions of deposit area}

The lenticular complex of the deposits carbonate rocks (dolomites, magnesites), characterized by fissurekarst permeability, represents an important aquifer for underground water. Owing to their large tectonic fracturation, dolomites and magnesites have suitable conditions for infiltration of precipitation waters and their circulation in the deeper parts of the massif. Chemical erosion has caused extensive karstification, especially in the zone of the preferred ways of infiltration - tectonic faults (Cicmanová 1995). In parts located high over the local base level, vertical groundwater streaming is prevailing. Horizontal direction of groundwater flow access in horizons close to base level and in deeper parts of the massif is markedly dominating (Halečka 1982). General direction of groundwater flow is from east to west, to the Mnísanský stream valley, where the whole structure was drained by the spring Teplá voda - Warm Water (295 m. over the sea level). During the mining progress around the depth of $200 \mathrm{~m}$ above sea level, a large water-saturated cave was opened by mining. It was $229.4 \mathrm{~m}$ above sea level. Large sudden inflow of water caused the flooding of the mine workings to the level of $308 \mathrm{~m}$. above sea level. After the retrieval of the mining works, a new drainage base for the western part of the Dúbrava massif was created. Consequently, the use of 
the spring Teplá voda for water management has been terminated. General direction of groundwater stream in the structure was from east to west, but following this event some changes in previous groundwater regime came into being (Lopusek \& Lukaj 1990). In the eastern part of deposit area these changes have resulted in slots formation along the Jordán stream. Sinking of surface water into the underground caused expressive change on the Jordán stream flows and herewith changed the total runoff of surface waters from the territory. According to the hydrogeological classification of mineral deposits Jelšava - Dúbrava massif is ranked as a deposit with difficult hydrogeologic conditions.

\section{Karst phenomenon}

Geomorphologic and hydrogeologic conditions of the deposit (base level, tectonic fractures of carbonate rocks, underground runoff of deposit) created suitable terms for development of a karstic phenomenon especially on and above the base level of the territory.

Karst occurrences are presented along tectonic lines and faults (preferably in places where they cross those), rarely on contact of two lithologically different rock types. Qualitative and quantitative different occurrences of karstification conditional to the velocity of groundwater circulation could be observed in separate parts of deposit.

Formation of the karst phenomenon has close relation to tectonics. There were discovered two types of karst systems. The first is genetically bound to the oldest tectonic system of E-W direction, localized particularly in the western part of the deposit. The second karst system is connected to younger fault tectonics of N-S or NE-SW direction, extended over the whole deposit.

The most ordinary and wide-spread karst occurrences, connected with youngest tectonics of N-S direction, are open caves, shafts and cavities of various shapes, permeable cave zones of various lengths, as well as tectonic faults filled by ochre and clay residuals from surrounding rocks or earthy mass brought by precipitation water. Colmatage of karst cavities and circulation paths causes water accumulation in more or less isolated reservoirs (up to $3,000 \mathrm{~m}^{3}$ ). Dangerous inflow of water could happen after the opening of these pools during mining. In the first moment, inflows could reach flow 10-150 1/s. In many cases after draining of static reserves inflows wholly stopped.

A large-scale horizontal system of caves, shafts (10 $m$ in diameter) and tunnels discovered on the $9^{\text {th }}$ horizon (400 m. above sea level) in the western part of deposit confirm existence of highly developed karst phenomena. It is genetically bound to the oldest tectonic system of E-W direction. Ochre filling, sinters and dolomite relicts are present there. Mining works found its west part first, where the width of the karstic cavity system is $45 \mathrm{~m}$, with an expected length of $400-500 \mathrm{~m}$. This system is probably connected to that in the eastern part of deposit (Jordán stream). Geophysical survey for tectonic faults in the mining area confirmed the existence of significant tectonic lines of E-W direction. The most critical are crossing zones where E-W faults are penetrated by N-S fault tectonics. Geophysical measuring realized by the Ukraine state institute (Kuznecov \& Osykin 1995) proved these assumptions in selected locations. Karst system probably and preferably developed in the drainage direction in consequence of base level changes in Neogene and Quaternary. There is the assumption of karst system occurrence in deeper horizons $(300 \mathrm{~m}$. above sea level).

Horizons under $280 \mathrm{~m}$. above sea level are considered as active areas of karst developing as whole structure, which is dewatering at present.

The unique aragonite Ochtina cave, situated in the Gemeric rock complexes of Spiš-Gemer Ore Mountains is also closely connected to magnesite rocks. In spite of this, speleologists pay little attention to cave exploring in magnesite complexes (Zenis \& Gal 1985, Pavlarcik \& Mitter 1996).

\section{Chemical composition of mine waters}

Natural waters connected to carbonate rocks of the deposit are of calcium-hydrogen carbonate type. Generally they contain higher contents of disulphates what suggest contact with Paleozoic rock environment with increased phon of sulphide sulphur (metapsammites, metapelites, volcanic complexes). There are no increased contents of metals in groundwaters. 


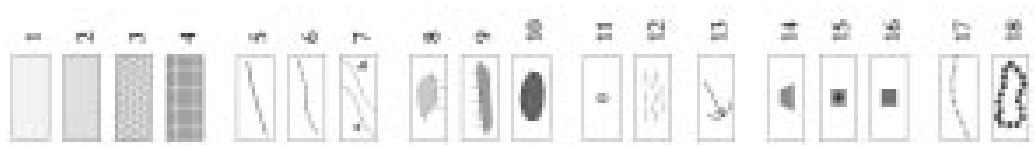

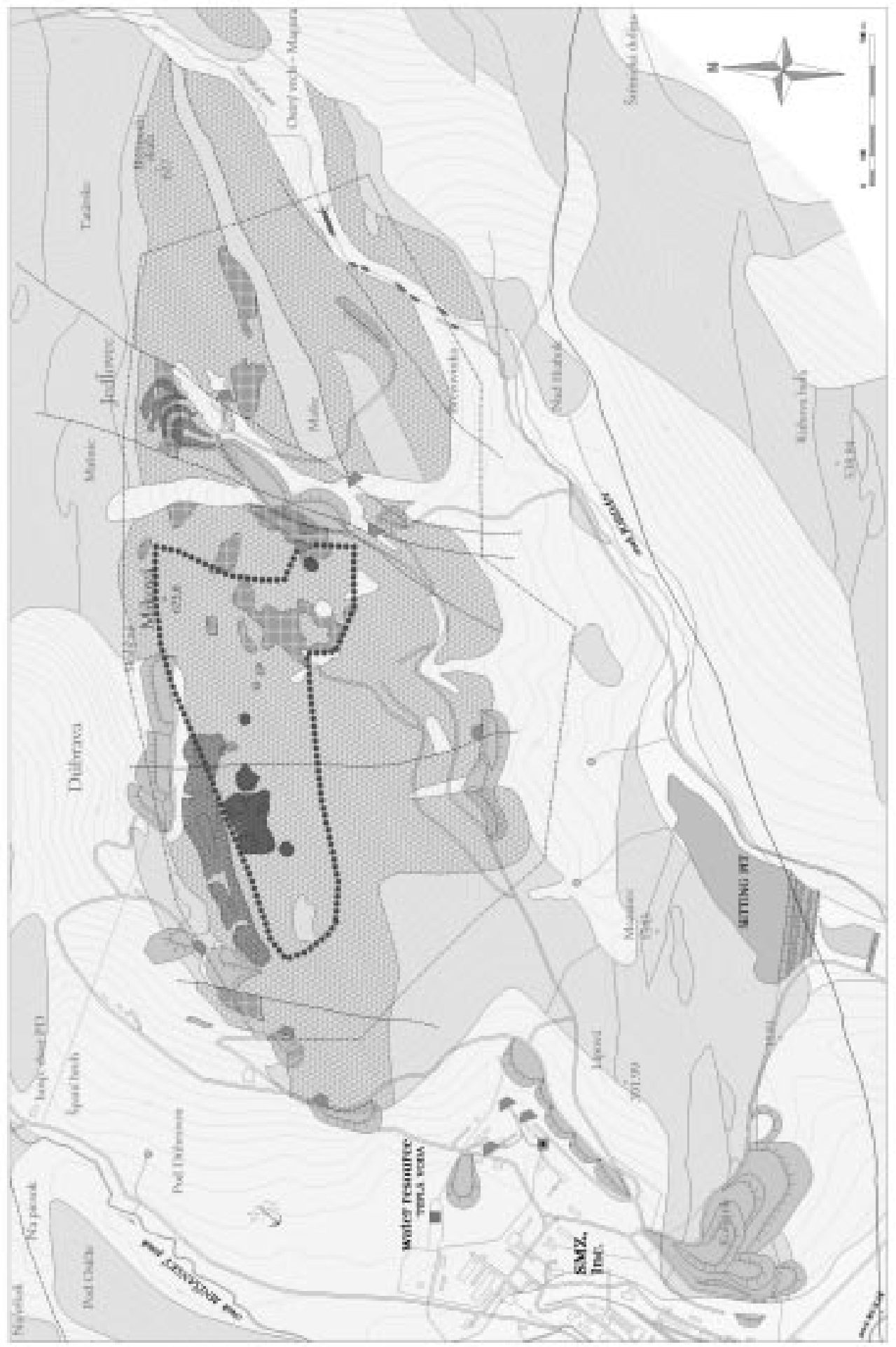

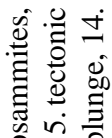

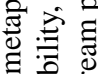

के के

㱐

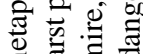

넌

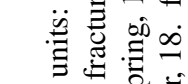

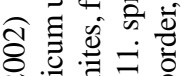

궁 हो

范

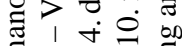

छิ

记氙

范

oे

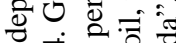

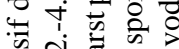

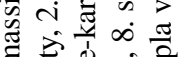

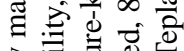

空司总

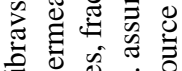

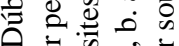

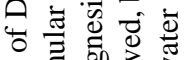

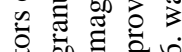

해임

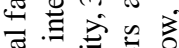

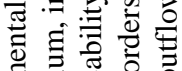

防

흥

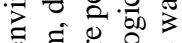

。

政

苛

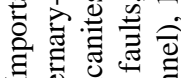

$\checkmark$ एँ

c

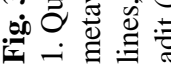




\section{Mining-technical conditions of exploitation and mining activity}

According to the calculated reserves, the Dúbrava massif magnesite deposit ranks among largest magnesite deposits in the world. Its lifetime is about 100 years, considering the present level of exploitation. Generally, the thickness of the deposit is about $200 \mathrm{~m}$, with a steep decline to the south. On the surface it represents ground elevations Dúbrava and Miková. Mining of the deposit started in the Dúbrava part by quarry in the past. The deposit was later opened by tunnels (adits) to deeper levels. Exploitation continued by underground mining under the base level of territory. At the present, active mining is on the $10^{\text {th }}$ horizon with $320 \mathrm{~m}$ in altitude. Mining to the level of about $200 \mathrm{~m}$ is being prepared for future realization.

The only mining method used in the horizons 7 (altitude $500 \mathrm{~m}$ ) and $8(450 \mathrm{~m}$.) was rooming, being enabled by suitable geomechanic characteristics of rock complexes. Exploitation has stopped there. After the liquidation of the safety pillar system large surface inbreakes and falls occurred in Dúbrava deposit part. The most extensive terrain falls, assessed as accident, were registered in 1992. There are still abandoned exhausted rooms in the Miková part of the deposit. Falls of terrain in undermined area happen in the present too.

Mining on horizon 9 (altitude $400 \mathrm{~m}$ ) will be finished soon. The flat back method of mining is used here now. Horizon 10 (320 m above sea level) is mined by flat back method in the Dúbrava part and by rooming method in the Miková part.

A flat back cut and fill method will be the only method of mining in the future on the deposit. Exploitation will be realised in deeper horizons of the Dúbrava and Miková deposit parts. Large open rooms will not be created by this mining method, therefore deformation of the top wall will be minimal. Occurrences of gradual settlement of terrain are expected in the future.

\section{Mining and mineral processing impacts on the environment}

Jelšava - Dúbrava massif belongs to regions with seriously damaged environment in relation to mining and mineral processing of magnesite. Efforts to stop this devastation and start the area's revitalization occured in the last decade after several environmental studies realized there by different institutions. The main geoenvironmental factors connected to magnesite mining and processing on the Dúbrava massif deposit are shown on Fig. 3. We can divide them into two groups (Cicmanová 1995):

- mining impacts

- mineral processing impacts

Mining impacts

These types of impacts are of primary character. They appear in mining area or immediate surroundings. Mining impacts often cause situations of emergency character:

- falls of terrain in consequence of undermining (deposit parts Dúbrava and Miková)

Formation of widespread slots and terrain falls in the Dúbrava and Miková deposit parts were caused by synergic effect of two factors. Natural conditions (geological, tectonic, hydrogeologic, geomorphologic, karst phenomenon) are base factors, which condition the massif stability and resistance against undermining. Tectonic faults of carbonate rocks together with karst development formed weak zones. Younger tectonic transverse tectonic lines of N-S direction and steep inclination - are important for interconnection of underground and surface. The second determining factor is the method of mining - rooming. Falling of terrain on localities Dúbrava and Miková is result of intensive mining by rooming method in the 1970s and 1980s.

Sudden destructions and falling of surface have negative effects concerning the job security in the course of mining process. Several studies were worked out by various institutions (Mining Institute of former Czechoslovak Academy of Sciences Ostrava, Technical University Košice, Mining University Ostrava, VUT Brno, SMZ Košice a o.) to solve this problem. The main topic was making and verifying the methodology for pressure and deformation measurement during the rock massif mining. The aims were to find out the best way (underground or surface) to make the liquidation of exhausted spaces and try to forecast after-effects (Piovarčiová 1989). The model tests, geophysical measurements, geodetic surface and underground monitoring were realized during the research. Based on these results, a seismic monitoring system began to be built to indicate sudden movements that would be a menace for mining workings. The monitoring system 
consist of tensometric measurements in boreholes (top wall movements), ultrasonic measurements in situ and seismic-acoustic measurements from offset scanners in the underground. Measurement point locations depends on the situation of the mined deposit part. Measured data are then computer processed and evaluated in an independent monitoring centre, placed in the mining plant. Measurements are targetted on obtaining data relevant to immediate menaces for mining workings.

\section{- destruction of significant water resources caused by mining works drainage}

Before the mining activity, the carbonate aquifer was naturally drained on the base level by the karstic spring Teplá Voda (average of $25 \mathrm{l} / \mathrm{s}$ ). The spring was exploited as a water resource for group water-supply. Mining progress to the depth caused drainage of groundwaters into the mining works and the spring gradually vanished. Many small-scale slots and terrain falls have appeared in the spring and surrounding area. Destruction of this important water spring resulted in searching for alternative water sources and required investments for their realization (Orvan 1987).

Progress of mining works depthward and extension of their drainage effects through the karst phenomenon gave birth to terrain falls in the valley of the Jordán stream, based on a significant tectonic fault. At present, slots in the Jordán stream cause permanent inflow of surface waters to underground and thereby changes of surface flow.

All groundwaters drained to the mine - mine waters - are used for processing of magnesite in neigbouring processing plant. Wastewater is discharged into the setting pit.

- spoil banks near numerous adit collars on Dúbrava-Miková slopes

Spoil banks from the mining activity are situated near every mine adit at various levels. The oldest spoils are localized in the highest parts of the massif, on the northern part of the Dúbrava ground elevation, near the old quarry. Material from the spoil banks is variated, from sand to boulders of $2.5 \mathrm{~m}$ size. Vegetation on spoils is very rare. Erosion processes of different intensities were documented there. In most cases flat and ravine erosion applied there, connected with slope flushing of spoil material. Spoil banks situated on lower levels (especially on the southern and eastern parts of the massif) contain other wastes too (building waste, old tyres). Locally, the waste from magnesite processing is placed here.

The Jedl'ovec deposit part was not exploited by underground mining. Only local quarrying, drilling and mine exploring activities were realized there up till now. No surface deformations are expected here at present (Cicmanová 1995).

\section{Mineral processing impacts}

Negative environmental impacts caused by the magnesite processing plant are of secondary character in relation with mineral mining. These impacts are of regional meaning. Air pollution and high dust fall interfere widely with the plant surroundings . Also spread of mineral waste dumps and setting pit is large.

- regional dust fall pollution and general environment alkalescence

Natural waters, soil and stream sediments were evaluated during research of geoenvironmental factors (Slama et al. 1999) and compilation of Geochemical atlas of Slovakia (2001). The most important findings related to the environmental pollution are:

Natural waters: Surface waters are polluted by $\mathrm{NO}_{2}$, $\mathrm{NO}_{3}, \mathrm{NH}_{4}$ and metals $\mathrm{Pb}, \mathrm{Zn}, \mathrm{Hg}, \mathrm{Sb}, \mathrm{Fe}$ and $\mathrm{Mn}$. High values of $\mathrm{pH}(>8)$ also contribute to the required quality of water. The worst situation is in Muráo River, especially near the deposit area. Besides inorganic indicators, including total content of indissoluble substances, organic elements (NEL, NOX) prove industrial pollution share. Concerning conditions and limits for drinking water, groundwater pollution with relation to magnesite mining was not confirmed.

Stream sediments: Increased values of metals in stream sediments were found only for $\mathrm{Cr}, \mathrm{Cd}, \mathrm{Hg}$ and As, mostly of local character. Increased As content is also conditioned by the sulphide presence in surrounding Paleozoic rocks. Contamination by other heavy metals was not identified here.

Soil: Consequences of magnesite processing resulted mainly in the decrease of soil fund quality in the surroundings of the plant, caused by the dust and gas emissions. Especially dust fall, consisting of caustic, very reactive magnesium oxide (generated under the 
temperature $800-1000{ }^{\circ} \mathrm{C}$ ) and undecomposed mineral burden from rotary and pit furnaces cause unfavourable effects. Settlement of dust elements in the surroundings was differently spread, depending on terrain morphology and air flow power (Slama et al. 1999). In conditions of hilly terrain and diffusion impairment, accumulation of exhalation elements could locally grow. Consecutive reaction with moisty environment forms a solid surface crust, covering large areas, which restrains vegetation growth and causes damage to the soil fund. The most negative indicator is high $\mathrm{pH}$ value (8-9.5), which results in changes of soil nutriment accessibility and terramare reduction in upper soil horizons.

\section{- mineral waste spoils from magnesite processing}

Mineral waste spoils are situated in several localities near processing plant, the largest one is located along the state road Jelšava-Revúca. Mineral waste contains various grain fractions native from magnesite mechanical processing and dust (powder) waste after heat treatment. Grey-brown solid crust of several $\mathrm{cm}$ in thickness is forming on powder and dust by influence of atmospheric factors and covers almost the whole southern part of the spoil bank. The formed crust is impermeable and quickens water runoff on and under spoil, what causes intensive erosion of primary terrain. Origin of solid crust is characteristic also for other localities in surroundings, damaged by intensive dust fall.

\section{- setting pit}

The building of setting pits started in 1968 in the lower part of the Jordán stream valley. The bottom of the valley is in an altitude of $283 \mathrm{~m}$, with maximal projected height of dam being $32 \mathrm{~m}$. Primary valley bottom consists of fluvial clays with gravel and sand layers, diluvial clays cover slopes of valley. Thickness of sediments is about $0.5-1.0 \mathrm{~m}$. Heavy weathered Paleozoic phyllites of earth and clay character are in underlying stratum. The body of the dam is built up by hydraulic stowage of processing plant materials, mainly cohesionless dust sands, consisting of quartz, magnesite, schist and phyllite grains and fragments.

Balanced accumulation reservoir is situated under the setting pit. There is no drainage built in the setting pit because settled materials are permeable. The embankment is not permeable and induces tides of seepage waters. An accumulating trench, built in the embankment crest, takes seepage water to the bulk tank. Also a concrete collector and armoured concrete pipes from the Jordan stream valley fall into this tank. It is used for water (rainwater too) drainage of the valley. However, the Jordan stream flow is low due to sinking of surface water into numerous terrain falls in the water-course. The stream flow is dimensioned for $14.4 \mathrm{~m}^{3} / \mathrm{s}$.

Water outflows from the bulk tank through the effluent object with installed water-stage recorder.

\section{Conclusions}

The Jelšava - Dúbrava massif belongs to regions with seriously damaged environment because of mining and mineral processing of magnesite. Efforts to stop this devastation and start the area revitalization occured in the last decade after several environmental studies realized there by different research institutions. Mentioned efforts were almost wholly targeted on solutions for secondary impacts of regional scale (dust fall), caused by magnesite processing. Primary impacts have been solved only additionally, mostly after accidents were activated by them.

\section{References}

Abonyi, A. et al., 1972 : Slovak magnesite deposits. Study. ŠGÚDŠ - Geofond, Spišská Nová Ves (in Slovak language).

Cicmanová, S.1995 : Magnesite deposit Jelšava - Dúbravský massif, CMS - geological factors. Script. ŠGÚDŠ - Geofond, Spisska Nova Ves (in Slovak).

Čapo, J., 1988 : Final report of exploration on deposit Dúbravský massif - magnesite. Script. ŚGÚDŠ - Geofond, Bratislava (in Slovak).
Halečka, J., 1982 : Dúbravský massif - detailed exploration. Hydrogeological assessment of magnesite deposit. Script. ŠGÚDŠ - Geofond. Bratislava (in Slovak).

Kuznecov, I.V.- Osykin, M. K. 1995, : Mapping of zones with high development of fall - subsidence processes due to mining workings on deposit Jelšava (by PIEM P- Z method). Script - Ukraine State Institute for minerals Simferopol. Archive SMZ a.s. Jelšava (in Slovak). 
Team of authors, 1980: Atlas of Slovak Socialist Republic. SAV Bratislava (in Slovak).

Team of authors, 2001: Geochemical atlas of Slovak Republic. Ministry of the Environment of Slovak Republic, Bratislava (in Slovak).

Lopusek, J.- Lukaj, M. 1990 : Dúbravský massif - prospecting, hydrogeological exploration - water. Script. ŠGÚDŠ Geofond. Bratislava (in Slovak language).

Orvan, J., 1987 : Teplá voda (Warm water), alternative water source, hydrogeological exploration. Script. ŠGÚDŠ Geofond. Bratislava (in Slovak).

Pavlarcík, S., Mitter, P. 1996 : Some information about karstification of magnesites in Jelšava surroundings. Script. Archive TANAP Tatranska Lomnica (in Slovak).
Piovarčiová, V. 1989 : Expert's report on mining impacts to surface, with possibility of mining to the level $200 \mathrm{~m}$ above sea level on deposit Dubravsky massif. Script. Archive UVR Košice (in Slovak).

Slama, M. et al. 1999: Set of regional maps for the environment geofactors, region Jelšava-Lubeník - Hnúš•a, scale 1: 50 000. Script ŠGÚDŠ - Geofond. Bratislava (in Slovak).

Tréger, M., Baláž, P. 2001: Economic assessment of magnesite and talc deposits in the Slovak Republic. Mineralia Slovaca, 33 (2001), pp 527-534.

Zenis, P.- Gaal, L.,1985: Caves in magnesites of Dúbrava massif. Magazine USOP Vyskum a prieskum, pp. 3-11 (in Slovak). 